\title{
PAULINE THEOLOGY OR PAULINE TRADITION IN THE PASTORAL EPISTLES: THE QUESTION OF METHOD*
}

\author{
Philip H. Towner
}

\begin{abstract}
Summary
This article re-examines the common positioning of the Pastoral Epistles at the transition from second to third generation Christianity. While there is validity in recognising theological development in the Pastoral Epistles, this need not be explained in terms of late discontinuity with Pauline theology; unnecessary methodological assumptions lie behind such a view. It is more likely that the Pastoral Epistles develop Pauline theology at the juncture of first and second generation Christianity.
\end{abstract}

\section{Introduction}

How is the theology of the Pastoral Letters to be understood in relation to the theology of the earlier Paul? In an opening discussion of methodology in her recent work on the theology of the Pastoral Epistles (PE), ${ }^{1}$ Frances Young gives some sound advice: 'Theology is always earthed in a context' (p. 1), a context which must be reconstructed largely from the evidence contained in the texts themselves (p. 2). From the relevant texts we gain an access to the culture, language and some of the assumptions of the writer and the community for which the letters were written. Young finds that in order to assess the theology of the Pastorals,

\footnotetext{
* I am grateful for the assistance given by Prof. Howard Marshall and Revd. George Wieland, who read and commented on early drafts of this paper.

1F. Young, The Theology of the Pastoral Letters (Cambridge: Cambridge University Press, 1994).
} 
comparison is particularly important, especially comparison with other early Christian literature, not least the letters of Paul, for the relationship between these three brief letters and the other evidence we have about early Christianity can alone help to determine their date, background and tradition... Yet we cannot entirely escape from the problem that reconstructing context and tradition depends on reading the very texts that we wish to elucidate through that reconstruction. This creates a problem of method. It is all too easy to set up an interpretative framework in advance which then determines how the texts are read (p. 3).

And that is just the problem we face in modern scholarship on the PE, but much of the reason for this goes back to the last century and first half of the present century.

The influence of especially F.C. Baur and Martin Dibelius can still be felt in modern studies of the Pastorals. Baur endowed New Testament scholarship with a rigid dialectical paradigm, whereby early, genuine Paul could be identified primarily by the Jew/Gentile debate, and later writings by its resolution (or absence) and by 'early catholic' tendencies. This understanding of history and interpretation set the Pastoral Epistles into the second century, as if in concrete. ${ }^{2}$ Dibelius' contribution, if it can be called that, was to interpret the Pastorals as projecting a general view, divorced from any particular historical situation, of a Christianity which had become secularised. ${ }^{3}$

Nevertheless, modern scholarship has clearly moved on, though not without paying heavy dues to the past. The new consensus is characterised by three elements. First, the PE are recognised as presenting a coherent theological and ethical argument to a real church or churches somewhere in time; this is a true advancement in understanding.

2F.C. Baur, Paulus der Apostel Jesu Christi (2 vols.; Leipzig: Fues-Verlag, 1866-67; reprinted Osnabrück: Zeller, 1968) 2:108-116; $c f$. the refinements in the application of H.J. Holtzmann, Die Pastoralbriefe kritisch und exegetisch bearbeitet (Leipzig: W. Engelmann, 1880) 84-252.

${ }^{3} \mathrm{M}$. Dibelius and H. Conselmann, The Pastoral Epistles (Hermeneia; Philadèlphia: Fortress, 1972). 
Second, attention is concentrated on the differences and distinctiveness of the Pastor's theology. Differences discovered far outweigh any points of contact with the early and undisputed Paulines. And these differences are regarded as 'findings' upon which a theory of their relation to Paul can be built. The distinctiveness of their theology and situation, over against that of the earlier Paul, demonstrates discontinuity. Paul was absorbed with the Jew/Gentile problem and with works of the law and faith, but in the PE such things are no longer relevant, and their dominant issues of succession and transmission of the gospel and ecclesiology are foreign to the earlier Paul. The differences are too great; Pauline theology has clearly spun off into a completely new orbit.

The third element of the current consensus is the view that these letters belong to a late period when the transition from second to third generation Christianity was occurring. Consequently, the theology of the PE has to be understood in terms of Pauline tradition not Pauline theology. 4

This consensus has constructed a rigid interpretative framework that rests on assumptions. The assumptions power the current methodology and both determine, and in some ways restrict, the understanding of the theology of the Pastorals that results. I am interested both in what is useful and misleading in this approach, but the interpretative framework, with its concentration on differences and lateness, needs to be

4J. Roloff, Der erste Brief an Timotheus (EKK 15; Zürich: Benziger, 1988); L. Oberlinner, Die Pastoralbriefe: Erste Folge; Kommentar zum ersten Timotheusbrief (HTKzNT XI/2; Freiburg/Basel/Wien: Herder, 1994); N. Brox, Die Pastoralbriefe (RNT 7; Regensburg: F. Pustet, 1969). Less detailed commentaries such as V. Hasler (Die Briefe an Timotheus und Titus (Pastoralbriefe) [ZBNT; Zürich: Theologischer Verlag, 1978]) and H. Merkel (Die Pastoralbriefe [NTD 9/1; Göttingen: Vandenhoeck \& Ruprecht, 1991]) confirm the consensus that the PE are second-century or late first-century documents which will only ever be understood with this in mind. And these are just the commentaries. Significant monographs and detailed articles provide the grist for this particular mill. The list here is much longer, but P. Trummer, H. von Lips, D.C. Verner, L.R. Donelson, M. Wolter and most recently F. Young would have to be included, and Roloff's name would reappear (see notes below for references). 
examined, and an alternative way of viewing the theology of the Pastorals needs to be considered.

\section{The Current Methodology}

J. Roloff has probably thought more than most about methodology in approaching the interpretation of the PE, and it must be said that his application has been consistent. ${ }^{5}$ His general orientation is as follows. The PE are pseudepigraphical, a point which need no longer be challenged. They are a unique literary corpus with the New Testament, which reflects a fully developed theological and ecclesiastical situation in contrast to the genuine Paul. They belong to an early second-century setting (though some among this consensus are happy to place them late in the first century), in which an expectation of the end is no longer an evident influence for life. This changed outlook forced the church to adjust to living in relationship to the society in which it exists. Its challenge is to maintain the continuity of the gospel in this changing time. The appearance of heretics heightens that challenge.

With the awareness that these letters have been carefully crafted, rather than being simply so many pieces of tradition thrown together, has come an increased interest in the mind behind them. The group of decisions introduced above forms the basis from which a profile of the author can be constructed. 6

Writing in Paul's name, the pseudepigrapher implies that he understands his task to be to interpret Paul. He knows Paul's letters, as his use of them indicates. He assumes his

${ }^{5}$ See J. Roloff, 'Pfeiler und Fundament der Wahrheit: Erwägungen zum Kirchenverständnis der Pastoralbriefe', in E. Grässer \& O. Merk (eds.), Glaube und Eschatologie (Tübingen: J.C.B. Mohr [Paul Siebeck], 1985) 22947; cf. also his Apostolat-Verkündigung-Kirche (Gütersloh: Mohn, 1965); Der erste Brief an Timotheus, 23ff.; and Die Kirche im Neuen Testament (NTD 10; Göttingen: Vandenhoeck \& Ruprecht, 1993) 250-67.

${ }^{6}$ See Roloff, Der erste Brief an Timotheus, 23-39, 376-82; Oberlinner, Die Pastoralbriefe, xlii-1; P. Trummer, Die Paulustradition der Pastoralbriefe (BET 8; Frankfurt: Lang, 1978); M. Wolter, Die Pastoralbriefe als Paulustradition (FRLANT 146; Göttingen: Vandenhoeck \& Ruprecht, 1988) 11-25, 245-56. 
readers have this knowledge of the Pauline correspondence as well. As interpreter, he does not aim to supplant the genuine Pauline letters and so eliminate the influence of Paul. Rather, he will appeal to the firm basis of the Pauline gospel (using the name of the apostle) to provide solutions to the new problems of his situation. The author does not create his own theology (as concepts such as 'deposit of tradition' [ $\pi \alpha \rho \alpha \theta \dot{\eta} \kappa \eta]$ show); he has consciously limited his own task to interpreting Paul for later practical situations for which the already existing Paulines lack the necessary practical teaching. ${ }^{7}$

The pseudepigrapher's procedure includes selecting materials and transforming them, which results in new emphases. Careful observation of this process will reveal the student's own position. Sometimes he becomes more than an interpreter; it may happen that he pushes certain aspects of theology so much into the foreground that they become independent entities and overpower the work of the master who is being interpreted. Consequently, the author's intention to present a programmatic Paulinism cannot guarantee that the resultant theology is actually representative of Paul.

With the pseudepigrapher's self-awareness and task thus understood, any attempt to interpret the PE will start from the frame of reference provided by the genuine Paulines. The goal will be to see to what extent the author remains true to his self-understanding only to interpret Paul, and where he exceeds Paul. In this way the PE can be located within Paulinism. But the author's own location will be determined not by agreement with Paul but by the points at which he disagrees with or exceeds him.

This, then, is an overview of the interpretative framework of Roloff and the consensus he represents. It may not be immediately apparent from this orientation, but the starting-point of this approach is established by a most fundamental question: Why would a church or a person in the early second century write documents such as the PE?

${ }^{7}$ Cf. G. Kretschmar, 'Der paulinische Glaube in den Pastoralbriefen', in F. Hahn \& H. Klein (eds.) Glaube im Neuen Testament (Festschrift H. Binder; BTS 7; Neukirchen-Vluyn: Neukirchener Varlag, 1982) 135-36. 


\section{The Application of the Current Method}

Although it is not usually the first thing to spring to mind when considering Pauline theology, the theology of the church is perhaps the most dominant aspect of theology in the Pastorals. It has been an important indicator for modern scholarship in determining the nature of the author's theology. In terms of the question of the PE in relation to earlier Paul, a look at this one aspect of theology and the methods employed by interpreters may provide a model for considering other aspects of theology. As a point of entry, we will introduce the consensus view of the church in the PE as understood by Roloff.

Most discussions of the church in the PE are organised around four themes or principles and two texts in which those themes converge. The four themes act as benchmarks in relation to which the continuity and discontinuity between Paul and the PE can be assessed.

The place given to the local community is our first benchmark. For Paul the local community is the place where God's eschatological people takes concrete form. Paul the apostle envisages his calling to be to plant communities like this and to protect them from dangerous movements. Some see this principle of organisation to become less and less the norm as the first century wears on: circles (such as the one centred on John) broaden out, and the outward movement of the so-called Palestinian, Jewish Christian wandering prophets from AD 70 onwards plays a contributing role. 8 The letters to the seven churches in Revelation 2-3 presume that until the end, the Pauline communities exist as local churches. In 1 Timothy and Titus a slightly different chord is struck, showing Paul's coworkers to be charged with the task of leading, structuring, and thereby stabilising and consolidating the Pauline church.

As in the earlier Paul, ${ }^{9}$ so in the PE the two dimensions of local (1 Tim. 3:5; 5:17) and universal (1 Tim. 3:15; 2 Tim. 2:19-

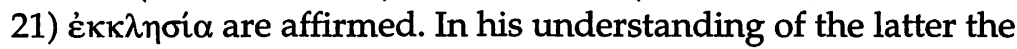

8U.B. Müller, Zur frühchristlichen Theologiegeschichte (Gütersloh: Mohn, 1976).

${ }^{9}$ See M.E. Thrall, A Critical and Exegetical Commentary on the Second Epistle to the Corinthians, vol. I (ICC; Edinburgh: T. \& T. Clark, 1994) 89-93. 
writer goes beyond Paul, but he shares with the apostle the belief that the concrete realisation of the church in any time must occur in the local community of believers.

A second benchmark is the salvation-historical, eschatological context of ecclesiology. For Paul the church is the End-time people of God. It receives the rights and promises of the Old Testament covenant people; the church's existence stands in tense contrast to the failure of Israel to believe. Here the PE distinguish themselves from Ephesians; for the church in Ephesians, the thought of the eschatological coming together of Jew and Greek is fundamental (see also Revelation, where the church is viewed as the people of the twelve tribes). The PE mention the 'people of God' motif once in Titus 2:14, but as part of a larger traditional piece, it receives no emphasis. Roloff suggests that the absence of the Jew/Gentile dimension is understandable, since the PE represent Gentile Christianity where it was no longer necessary to justify the claim to be the people of God in the dispute with Judaism. The Gentile church is simply the normal state of affairs; the challenge of Judaism has been replaced by the challenge to find its place in Gentile society. There is here a distance from Paul which only time could create.

The third theme that acts as a benchmark in the issue under consideration is the relation of the church to the gospel. Paul and the PE agree that the church is the fruit and result of the proclamation of the gospel. First, the gospel is entrusted to Paul, and from this the whole church has come into being, because in the gospel the saving power of the Christ-event is demonstrated. The PE make clear that the word of God can be preached and heard in the church and remains distinct from human words which lead to confusion.

But as this theme develops, there are two unmistakably new aspects. First, 'teaching' has taken the place of 'preaching' as the central activity associated with the word of God. When the Spirit speaks in the PE (1 Tim. 4:1), the message corresponds to the past revelations of God's will, transmitted through Scripture and traditions of the faith. The church of the $\mathrm{PE}$ is a teaching church; church officers are teachers while members are hearers. 
Second, the concept of tradition has assumed a new shape through the term $\pi \alpha \rho \alpha \theta \dot{\eta} \kappa \eta$. It expresses the idea of an unchangeable deposit. Whether the church stands or falls depends upon leaders who are qualified to guard this deposit. Behind this invention Roloff sees the problem of continuityhow does the church as it moves from the second to the third generation keep its teaching intact, especially in the context of heresy?

The fourth benchmark is the place and nature of church office/ministry/leadership. This is a dominant feature in the ecclesiology of the PE. Timothy and Titus are presented as types of the community leaders, and all office-bearers to come are appealed to through them. But the structure does not come to our author through Paul, but through his own experience of the church in his own historical and geographical situation. Roloff argues that what is normative is not the office structure, but the theological themes which undergird the concept of 'office'. In these, the author links himself to Paul, but only in a superficial way. His structure begins with the traditional picture of Paul the apostle to the Gentiles. Paul's relation to the gospel is authoritative, a theme developed from the historical Paul (1 Cor. 1:1; Rom. 1:1); he not only founds churches, he also leads them and experiences the fullness of life with them, in person and through letters. From time to time he also appoints those from his team to serve as deputies, at least temporarily. And he presents himself as the model for the life of faith. The genuine Paul employs other, more dynamic metaphors, such as the 'body of Christ' with its associated discussions of the charismata possessed by all of its members. There are certainly special functions and functionaries noted in Paul, such as the apostles, prophets and teachers (1 Cor. 12:28), but a uniform line of authority within the local church is missing (1 Cor. 14:26; Rom. 12:7; 1 Cor. 12:8).

The pattern of church order reflected in the PE indicates change when compared with Paul. Now the apostle is seen as extending the task of leadership to his co-workers for an indefinite period of time, and he gives commands to see to the future church's leadership needs (1 Tim. 5:17-22). Now Timothy and Titus function for the communities as ideal types 
of the community leaders; they are to guard the deposit of teaching just as Paul guarded the gospel; and they, instead of the apostle, are seen as having lives completely shaped by and committed to the gospel, even to the point of suffering. Thus, what the author passes on is not simply a form of church organisation, but an interpretation of the theological significance of church order. He attempts to follow a Pauline pattern, but the absence of both the apostle and the charismata represents a deficit which must be filled in other ways.

In relation to these four themes, consideration needs to be given to central ecclesiological texts. The four themes just explored converge in 1 Timothy 3:15 and 2 Timothy 2:19-21, texts which most regard as central to the theology of the church, and in which the most influential metaphor is that of the household. ${ }^{10}$ In employing the household imagery, the author allegedly takes a final step away from Pauline theology by depicting the church as the permanent historical social entity in the world. The church has become an institution. The two key passages contain Pauline echoes, but the image of the church belongs to the third generation. In order to consider 1 Timothy 3:15 in some detail, 2 Timothy 2:19ff. will be passed over in our discussion.

1 Timothy 3:15 forms the conclusion to the first section of teaching to the community in 1 Timothy 2:1-3:13. The verse explains the writer's motive for writing, and in this way establishes the major theme of this section of the letter 2:1-3:16 (and possibly of the whole letter): behaviour in the household

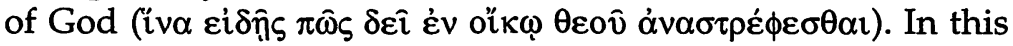
context a striking description of the church appears. The relative clause which follows determines that the household of God is the church of the living God, pillar and foundation of

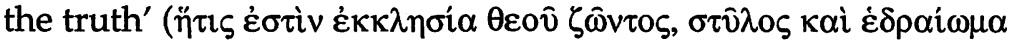
$\tau \hat{\eta} \varsigma \dot{\alpha} \lambda \eta \theta \varepsilon i \alpha \varsigma)$. But the meaning of the imagery is not automatically clear.

10Roloff, 'Pfeiler', 238-46; idem, Kirche, 254; A Weiser, 'Die Kirche in den Pastoralbriefen', BK 46 (1991) 107-113; Brox, Pastoralbriefe, 157-59; Oberlinner, Pastoralbriefe, 156. 
The background to 'the household of God' concept is the Greco-Roman household.11 It is this image that makes most sense of the shape which the Christian life assumes in the PE, with its lines of authority and responsibility. Use of household codes (1 Tim. 2:15; 6:1-2; Tit. 2:1-10), the concern for children (1 Tim. 3:4; Tit. 1:6), widows (1 Tim. 5:3-16) and slaves (1 Tim. 6:12; Tit. 2:9-10), and especially the analogy between the church leader and the householder (1 Tim. 3:4-5, 12; cf. Tit. 1:7, $\theta \varepsilon 0 \hat{v}$ oikovó $\mu$ ○) are part of the household pattern of church identity employed in the PE. Just as there are rules of accepted behaviour, relationships to observe, and responsibilities to fulfil within the household, so there are analogous patterns to be observed in God's church. Believers must therefore know how to behave in God's household (1 Tim. 3:15).12

But for Roloff and many others the social household ecclesiology in this passage gains a sense of historical and religious permanence and, therefore, thorough-going institutionalisation through the additional combination of metaphors. First, the image of the temple is traditionally the most suitable device for referring to the presence of God. But the term 'temple' is missing from our passage. The phrase

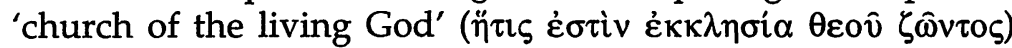
which defines 'the household of God' is thought to depend upon 2 Corinthians 6:16. There the temple is the central image:

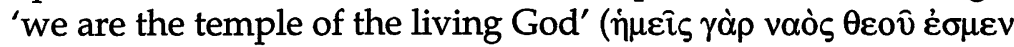
$\zeta \hat{\omega} v \tau \circ \varsigma)$. Of course Roloff does not know for sure that 2 Corinthians 6:16 is in mind, but the Pauline language here suggests to him that the connection is likely; elsewhere the

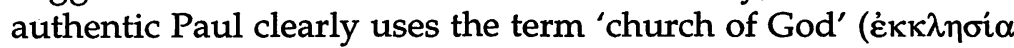
$\theta \varepsilon 0 \hat{v}$, as in 1 Cor. $1: 2 ; 10: 32 ; 11: 2 ; 15: 9 ; 2$ Cor. $1: 1$; Gal. 1:13; cf. 1 Cor. 11:16; 1 Thess. 2:14; 2 Thess. 2:4), and he designates God as 'the living God' on at least two occasions (2 Cor. 6:16 and 1 Thess. 1:9; cf. Acts 14:15).

\footnotetext{
11See D.C. Vertner, The Household of God: The Social World of the Pastoral Epistles (SBLDS 71; Chico, CA: Scholars Press, 1983); Roloff, Der erste Brief an Timotheus, 197-99; idem, 'Pfeiler', 236-37; H. von Lips, Glaube-GemeindeAmt (FRLANT 122; Göttingen: Vandenhoeck \& Ruprecht, 1979) 143-50.

12See von Lips, Glaube, 122.
} 
The case for the temple allusion is thought to be established by the next phrase which describes the church of

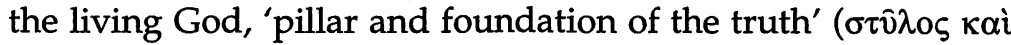
$\dot{\varepsilon} \delta \rho \alpha i \omega \mu \alpha \tau \hat{\eta} \varsigma \alpha \dot{\alpha} \eta \theta \varepsilon i \alpha \varsigma)$. It employs architectural imagery of the sort used elsewhere to describe the temple, but it is also the sort of language that could be used in figurative ways to describe support and solidity. And the key term often translated 'foundation', 'bulwark', or 'mainstay' ( $\dot{\varepsilon} \delta \alpha i \omega \mu \alpha)$ is linked to the specific idea of a 'foundation', as opposed to other alternatives, and to the temple through the use of a related term $(\dot{\varepsilon} \delta \rho \alpha \sigma \mu \alpha)$ in the LXX (cf. $3 \mathrm{Kgs} .8: 13 ; c f .1 \mathrm{Kg} .8: 13 \mathrm{MT})$. The Qumran sect described itself with similar phrases as the 'firm foundation of the truth' (1QS 8:5; cf. 8:8; 9:3-4) in the sense of 'the true temple of Israel'. ${ }^{13}$ Here, at least, temple imagery and truth are linked together. The Qumran community felt itself to be firm and secure because it was the recipient of the revelation of God's truth. This in Roloff's mind provides a better parallel for the presence of temple thought and the connection with the truth in our passage.

The first term in the phrase, 'pillar' ( $\sigma \tau \hat{v} \lambda \circ \varsigma)$, is not necessarily the supporting structure of a building. On the model of the Old Testament pillar of cloud (Ex. 13:21), it may be understood as a sign. 14 This corresponds to the church's responsibility to testify to the world.

These are the basic parts of the church picture. While the household metaphor in and of itself is a dominant and perhaps controlling factor in the way the church is now understood, the complete theology of the church depends upon how the rest of the parts fit together and relate to 'the truth'. Some see the church as here described as being in the service of the truth (the genitive might thus be understood as an objective genitive); the church is therefore identified with the pillar and foundation, parts of an edifice which bear weight, and in this picture the church is described as supporting or bearing the

13Roloff, Brief an Timotheus, 200; B. Gärtner, The Temple and the Community in Qumran and the New Testament (Cambridge: CUP, 1965) 68-69; O. Betz, 'Felsenmann und Felsengemeinde. Eine Parallel zu Mt. 16,17-19 in den Qumrantexten', ZNW 48 (1957) 49-77, 57.

${ }^{14}$ See von Lips, Glaube, 99. 
truth. 15 Roloff understands the genitive 'of the truth' $\tau \hat{\eta} \varsigma$ $\dot{\alpha} \lambda \eta \theta \varepsilon i \alpha \varsigma$ as a qualitative genitive which describes something intrinsic to the pillar and foundation. Thus the church is not compared with a foundation which bears something else; he insists it cannot be that, because that would be to compare a complete edifice, the church and the household, with just a part of it-the logic is, the whole cannot be identified with the part. Rather, the church is described not as a part of a building which supports the truth, but as a witnessing, firm and unshakeable entity (a Gründung) because it is determined by the truth. 16

Thus, either the church is described as being firm and safe because it is the institution determined by the truth in which the truth dwells, or it is firm and unshakeable in serving the truth because the living God indwells it. Both ideas can possibly be in mind, but either way the church does not enclose this truth as a holy shrine, but is to confess it openly to the world. Like the pillar of cloud in the Old Testament experience, the church as pillar of the truth shows the truth of God to the world.

In and of itself, this exegesis is not remarkable. There is some variation within the consensus, but there is complete agreement when it comes to the question of how this picture of the church is held to be related to Paul. Even with allusions to 2 Corinthians 6:16 and the temple, which might seem to suggest a line of continuity from Paul, the picture is thought to lack Pauline depth. This is where the themes introduced above come into play.

${ }^{15}$ E.g. Brox, Pastoralbriefe, 157.

16Roloff, 'Pfeiler', 240-41; idem, Der erste Brief an Timotheus, 200. Oberlinner (Pastoralbriefe, 160) takes 'of the truth' to be a genitive auctoris-the church has been produced by the (proclamation of the) truth. The meaning of 'the truth' is significant for Roloff. Many equate it with the gospel (or $\pi \alpha \rho \alpha \theta \dot{\eta} \kappa \eta)$, which seems the most natural meaning (e.g. Oberlinner, pastoralbrief, 159; von Lips, Glaube, 99; Brox, Pastoralbriefe, 69; E. Schweizer, Church Order in the New Testament [SBT 32; London: SCM, 1961] 79). Roloff, however, maintains that the event of Christ related in v. 16, to which 'the truth' refers, transcends the gospel message. Thus truth becomes a broader, more fundamental description of a christological or pneumatological reality-a way of life ('Pfeiler', 241). 
First, the thought of the indwelling of the Holy Spirit in the temple is missing. Thus the picture of the church as household and temple is a static picture not of the end-time people of God but of the practical and ordered association of people who seek to maintain a religious dimension to their identify. This people will reveal God's salvation by their confession of the word and their behaviour in the world. As Schweizer puts it, the key element in understanding the church of the PE is social organisation. ${ }^{17}$ It is a social, not a spiritual church, whose main theological concern is christology as codified in the traditions, not pneumatology which is more characteristic of times past when the Spirit was experienced spontaneously in the life of the believer and community. ${ }^{18}$ The thought of the Spirit as an active force in the present life of the believer is only on the periphery (Tit. 3:5). 19 What the Spirit does in the PE is to guarantee the continuity of the tradition (2 Tim. 1:14), to authenticate past words for the present time (1 Tim. 4:1).

Second, the picture of growth and development is gone in the PE. The image is of completion, maturity, solidity instead of planting and growth. There is no longer an eschatological dimension; the historical has completely swallowed this up. 20 According to Paul, the presence of God was now in the community of believers of Jesus Christ which is filled with God's Spirit and which is the temple (1 Cor. 3:16; 2 Cor. 6:16). Paul describes the church as a building whose foundation is the apostle's testimony of Christ (1 Cor. 3:11). Somewhat later, Ephesians adopts this picture but widens out the viewpoint of growth from a salvation-historical perspective; now the church grows as the temple of God from the foundation of the

${ }^{17}$ Schweizer, Church Order, 78-80; cf. Brox, Pastoralbriefe, 157-58.

18Roloff, 'Pfeiler', 242.

${ }^{19}$ Ibid, 238.

${ }^{20}$ According to Roloff ('Pfeiler', 242-46; idem, Kirsche, 259-61), the picture of the church in 2 Tim. 2:19-21 coincides with 1 Tim. 3:15. Both the temple (v. 19) and the household metaphors (vv. 20-21) are in play, and the image of permanence is dominant. Within its passage of parenesis, ecclesiology cuts in a slightly different direction, but there too the church is depicted as the permanent institution in the world. $C f$. Weiser, 'Kirsche', 110-112. 
apostolic tradition (2:20), heading towards its fulfilment in Christ (2:21-22). But the church in the PE has become a static entity.

Where would the pseudepigrapher's theology of the church belong in the stream described as Paulinism? The four themes or benchmarks considered above reveal a picture of theology that relates to Paul in varying degrees. According to Roloff, continuity and development is perhaps evident at certain points. But divergence and discontinuity, most evident in a specific ecclesiological text, indicate a distance from Paul that is decisive. The theology of the PE is not to be assigned a place with Pauline theology, but rather belongs to something more safely called Pauline tradition; i.e. a combination of genuine applications of the theology of the Hauptbriefe and later developments for which Pauline authentication is sought.

\section{Pauline Theology or Tradition: The Question of Method}

Proponents of authenticity might well wish to take issue with this prevailing interpretation. But even if, on the exegetical level, a number of points would be disputed and won, it is doubtful that the picture of the church in the PE could be convincingly made to fit precisely into that of the Pauline Hauptbriefe, and it is even questionable whether such a project would be a worthwhile one to engage in. But if retreating to the opposite extreme is not the best way to respond to Roloff and others of the consensus, what sort of response is possible? There is a solution which takes full account of the distinctiveness of the PE as emphasised by Roloff, et al. without becoming enslaved to the methodology and the results it inevitably leads to-namely, post-Pauline writings addressing non-Pauline situations. We shall establish this position first by offering some criticism of the methods behind the interpretation just introduced. Some bear closely on specific aspects of exegesis, and the exegesis is in need of adjustment in some places. Following this step, I will make a suggestion for an alternative placement of the PE within Paulinism. 


\section{A Critique of Assumptions and Method}

First, consideration needs to be given to whether it is best to assume that the PE are second-century or turn-of-the-century documents? Roloff and others continue to be convinced by lexical studies (the relevance of which have been called into question through an awareness of the use of amanuenses and pre-formed materials) and nineteenth-century history of religion theories that have never been substantiated. Baur's influence has been tremendous, but the passage of over 150 years of negative or questionable test results ought to be sufficient to allow serious consideration of the possibility that nothing in the PE must be placed as late as the present consensus thinks. ${ }^{21}$

A second important methodological question must be that of the literary relation of the three letters. Assumptions here are related to a view of authorship and often to the question of date, and, as I will show in the case of Roloff, they affect the shape given to the theology of the letters. As is well known, the two letters to Timothy and the letter to Titus were grouped together under the title of the 'Pastoral Epistles' apparently in the early eighteen-century. This was originally done because of subject matter. It is arguable that they represent a corpus within the Pauline corpus due to vocabulary and other interests shared. But, apart from more modern theories of pseudonymous purpose which require literary unity, ${ }^{22}$ or Quinn's third volume of Luke approach, ${ }^{23}$ there are

21See E.E. Ellis, 'Die Pastoralbriefe und Paulus: Beobachtungen zu Jürgen Roloffs Kommentar über 1. Timotheus', ThBeit 22 (1991) 208-12; M. Prior, Paul the Letter-Writer and the Second Letter to Timothy (JSNTS 23; Sheffield: Sheffield Academic Press, 1989) 13-35. Pseudonymity as such, i.e. nonPauline authorship, is a possibility and should be considered as such. But certainly a number of important questions are still open, and as a hypothesis it is possibly a questionable methodological starting point. For discussion, see Prior, Paul, 18-24.

22Even though explaining, for example, the purpose of Titus is problematic; Roloff, Der erste Brief an Timotheus, 43-45; see also Young, Theology, 136-69; Trummer, Paulustradition, 72-78, 97-105.

23J.D. Quinn, 'The Last Volume of Luke: The Relation of Luke-Acts and the OE', in Perspectives on Luke-Acts, ed. C. Talbert (Macon, GA: Mercer, 
no internal clues to suggest that they originated from the same place or time, or that they are to be read as one literary unit. Is it, therefore, justified to interpret the three letters as if they are one literary unit? That is, can one dominant feature in the presentation of the church in, for instance, 1 Timothy be assumed to be operative and therefore affect the understanding of the church in 2 Timothy and Titus as well?

Of course, the issue here is one of acknowledging that each letter possibly addresses a unique historical situation. The specific bearing of this can be seen in the conclusions drawn above about the church and the whole relationship of the theology of the PE to Paul from 1 Timothy 3:15. For Roloff the image of the church in 3:15-his church as the great historical institution in the world - becomes a kind of theological blackhole which exerts influence on every aspect of theology. Taking the letters separately would mean that 1 Timothy 3:15 provides a conclusion only to its own passage, and maybe does function as a high point of the whole letter. But it is not necessarily a view of the church that affects 2 Timothy or Titus. Thus the effect of this would be to reduce the dominance of the one great picture of the church down to the size appropriate to its literary function within its legitimate unit of discourse. Admittedly, 2 Timothy also employs household imagery to describe the church, but the images, created with somewhat different language, are put to different uses. In fact, specific exegesis suggests that the thoughts of permanence lent to the picture of the church by the imagery used in each case need not be thought of as historical permanence at all. And in Titus, though the thought of the universal people of God is also present (2:14), the main focus is on local churches, and household is not a term used to described the church. In any case, the assumption that the PE form a unified literary unit gives a weight to the interpretation of one passage that is possibly out of proportion to its actual purpose and function. The immediate result is that a single concept (whether or not it is correctly understood) is allowed to dominate the ecclesiology of the

1978) 62-75; idem, The Letter to Titus (AB 35; New York: Doubleday, 1990) $17-21$. 
three letters. A secondary result is that this dominating view then comes to play a decisive role in determining the relationship of the theology of the PE to authentic Pauline theology.

So much for broader concerns. We need to narrow the focus of our critique to questions which directly affect exegesis of specific texts. Roloff points out that the genuine Pauline letters must be the touchstone for determining the placement of the PE within Paulinism, and this is a sound bit of methodology. But this leads on to another serious question: Is the picture of genuine Pauline theology upon which most modern interpreters of the PE depend too static, too shallow, and thus really only a caricature? The relationship of the PE to the undisputed Paul considered above assumes that the limits of what is authentically Pauline theology have been set. In terms of the writings involved, we are to imagine a series of concentric circles: the innermost part consists of the Hauptbriefe-Romans, Galatians and the Corinthian letters; next come the deutero-Paulines (Ephesians, Colossians, 2 Thessalonians); and frequently the PE are relegated to the next circle out. We have already considered the exegetical and theological criteria employed to justify such distinctions (and which continue to be called into question), but a few are worth mentioning again The genuine Paul: was concerned with the Jew/Gentile issue; thought primarily of justification/salvation as being future; did not think in the cosmic categories of Ephesians; understood the church to be governed by the Spirit and not by those who hold an office; and so on. However, there is generally a rather curious omission of the first circle 'out from the centre', the genuine non-Hauptbriefe, i.e. 1 Thessalonians, Philippians and Philemon, in which, if compared with the Hauptbriefe, would be found evidence either of development or diversity that suggests a true picture of Pauline ecclesiology cannot begin and end with the Hauptbriefe. Baur tossed these writings into the deutero-Pauline bin, but most of those representing the consensus today would be reluctant to follow him completely.

This caricature of Paul affects the understanding of the church in the PE, as a second look at Roloff's approach will 
reveal. Some comparison will allow us to reopen the question of the relation of the PE to Pauline theology.

\section{A Critique of Method and Exegesis}

Above we noted Roloff's observation that both Paul and the PE share the dual concept of the church as local and universal. What he sees as unique to the interests of the PE is the attempt to preserve a concept of church that is Pauline-he seems to think that given developments away from the local church in Asia Minor this would be anachronistic. In any case, at this level the PE reflect continuity with Pauline theology, even if it is contrived.

A second line followed by Roloff is that of the Pauline eschatological or salvation-historical horizon of the church. Paul views the church as the end-time people of God, continuous with the Old Testament people of God, now made up of Jews and Gentiles, and in Ephesians the coming together of Jew and Gentile is fundamental to the church. Such thought is missing in the PE (except for the citation in Tit. 2:14). Roloff says this is understandable since the church now is a Gentile church and needs no longer justify its existence before Jews. Nevertheless, he claims that here we have divergence from Pauline theology. But do we? Granted that in the absence of the Jew/Gentile debate the need to describe the church according to the earlier categories might diminish or be completely irrelevant, we need to ask two questions: (1) did Paul always overtly conceive of the church in terms of the eschatological Jew/Gentile solution?; and (2) are there any indications in the $\mathrm{PE}$ of the eschatological fulfilment motif?

To answer the first question, 1 Thessalonians addresses what appears to be primarily a Gentile church. Jews are mentioned as enemies and as those who hinder the preaching of the gospel to Gentiles. The 'body of Christ' concept is absent from Philippians. In neither case is the problem of the relation of Jew and Gentile in Christ high on the agenda, and in neither case is it appropriate to conceptualise the church overtly as the end-time people of God as Paul does in 1 Corinthians 6 and 2 Corinthians, and as we find in Ephesians 2. But it is quite likely that the thought of the eschatological in-gathering of the 
Gentiles is primarily in mind in 1 Thessalonians 1:8-9 and 2:1516. This is not to say that Paul does not think of the church as the end-time people of God; rather, the imagery involved was not appropriate to the situation.

If we treat the PE as a corpus, it might be sufficient to answer the second question by saying that the concept of the end-time people of God is present in Titus 2:14. Roloff disallows this on the basis of that text's traditional characterwhich is a very weak argument. More importantly, within the passage concluded by 1 Timothy 3:15, which begins with 2:1, there are two indications that the church is viewed as the result of God's eschatological promise to gather in the nations. In 2:16 , several uses of the term 'all' emphasise the gospel as being the means of God's inclusive salvation; then verse 7 describes Paul as the preacher, apostle and teacher of the Gentiles. Following this, verse 8 probably alludes to Malachi 1:11,24 for the two passages share an interest in the universal Gentile worship of God, 25 only from different historical perspectives. Paul may well have this Old Testament text in mind in 1 Corinthians 1:2; 2 Corinthians 2:14 and 1 Thessalonians 1:8, as well.

Malachi 1:11 (RSV): For from the rising of the sun to its setting my name is great among the nations, and in every place (LXX: $\dot{\varepsilon} v \pi \alpha v \tau i$ ió $\pi \omega$ ) incense is offered to my name, and a pure offering; for my name is great among the nations, says the Lord of hosts.

1 Tim. 2:8: I desire then that in every place (غ่v $\pi \alpha v \tau i$ $\tau$ ó $\pi \omega)$ the men should pray, lifting holy hands without anger or quarrelling.

This would place the Ephesian church in the salvationhistorical position of being fulfillers of the Old Testament promise that the nations would worship God. This is very much an eschatological, salvation-historical conception of the

${ }^{24} \mathrm{Cf}$. Roloff, Der erste Brief an Timotheus, 126-27.

${ }^{25}$ Cf. Didache 14:2-3; Justin, Dialogue with Trypho 117:2. In the targums, this OT passage figures in discussions of prayer. 
church, and is hardly out of line with a Pauline view, even if it can be argued that it is a somewhat more finished view.

Roloff is right to identify the Gentile situation of this church as a natural reason for the absence of Jew/Gentile language; but he fails to observe the degree to which the church is thought of as the outworking of the Old Testament promises. The thought may be expressed for a Gentile audience unfamiliar with earlier divisions between Jews and Gentiles, but an eschatological, salvation-historical horizon is not missing from the PE. Here too there is more continuity than discontinuity with the Paul of the Hauptbriefe.

Roloff's third guiding theme is gospel and Church. Both Paul and the author of the PE conceive of the church as the fruit of the gospel. Roloff has a deficient view of the various activities associated with the gospel in the PE in choosing to emphasise teaching and the concept of the 'deposit of truth' $(\pi \alpha \rho \alpha \theta \dot{\kappa} \kappa \eta)$, and a better balance is needed. ${ }^{26}$ But we will allow that these are emphases which reflect new developments in the church's circumstances and outlook. The church is a teaching church, and its task it to mediate the already-formulated teaching of the faith, a part of its consolidation mentality. It is almost universally agreed that the reasons for the emphasis on teaching, whether or not historical situations are in view, are false teaching and the absence or departure of the apostle. The gospel which is the source of salvation is under attack and the church must preserve it. This interest corresponds to the church at a different stage from the earlier Paul-a stage of transition through which the continuity of the gospel must be safeguarded.

This transitional situation is very much in view in the changed approach to tradition indicated in the Greek concept $\pi \alpha \rho \alpha \theta \dot{n} \kappa \eta$. In the earlier Pauline literature, the technical

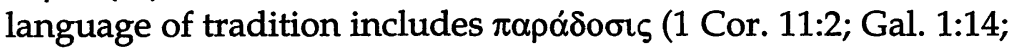
2 Thess. $2: 15 ; 3: 6), \pi \alpha \rho \alpha \delta i \delta \omega \mu \mathrm{u}$ (1 Cor. 11:2), and $\pi \alpha \rho \alpha \lambda \alpha \mu \beta \alpha \dot{v} v \omega$ (Col. 2:6), terms which play no part in the PE. Associated verbs

26See P.H. Towner, The Goal of Our Instruction: The Structure of Theology and Ethics in the Pastoral Epistles (JSNTS 34; Sheffield: Sheffield Academic Press, 1989) 121-28; von Lips, Glaube, 40-53. 


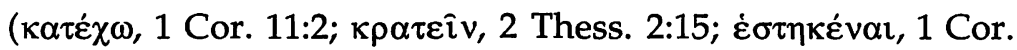
15:1) suggest that for Paul the interest was in accepting and maintaining the growing body of apostolic tradition. But the verbs associated with $\pi \alpha \rho \alpha \theta \dot{\kappa} \kappa \eta$ ( $\pi \alpha \rho \alpha \tau i \theta \eta \mu \mathrm{l}, 2$ Tim. 2:2; 1 Tim.

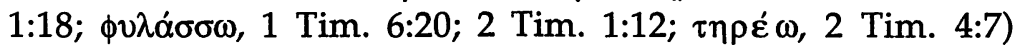
suggest a changed interest in protecting the deposit and transmitting it safely to future generations. ${ }^{27}$

The development in thinking is evident. But what is the development related to? The PE suggest that it is the transition related to the passing of the apostle. But what evidence is there that this places the author in the third generation of Christianity? If a development in thought is indicated in the text, how does one decide whether it is related to the transition from first to second generation Christianity or the transition from second to third generation Christianity? Roloff's concentric circles guide him through this tricky water. Is it so inconceivable that the need to think through the implications of the departure of the apostle dawned on a Pauline co-worker fairly soon after he departed? Could not the apostle himself have foreseen the implications of his passing for the church and the continuity of the gospel?

The fourth guiding principle in locating the ecclesiology of the PE was church order. There is here, according to Roloff, development and divergence. Paul's own sense of church order is mainly charismatic and located in the apostle, prophet and teacher; though he knows of the offices of bishop and deacon (Phil. 1:1), the lines of authority are looser. There are changes of emphasis in the PE. Paul is still appealed to as the centre of church order, but the co-workers are assigned to long-term deputation in a way not done by the earlier Paul. And they themselves become the models of the believers. It could be argued that the only shift is the recipient of the letters. Letters written by the earlier Paul to co-workers may well have stressed all of these things in the same measure. But if change is in view, it is change from what situation to what situation?

${ }^{27} C f$. von Lips, Glaube, 47-52. 
Several of the questions already asked converge at the point at which Roloff says the church of the PE steps fully away from Paul, namely, in the picture of the church as God's household, the great institution of the world. Whatever Paul and the PE share in common, at 1 Timothy 3:15, we are told, we arrive at the parting of the ways. This dominant image of the church as household is one of completion and immovability. It is a social and historical institution. Why? Because of the household concept and lack of the Pauline emphasis on the Spirit and growth. We have already seen above that Paul is capable of referring to the church without such things overtly in view.

Consideration needs to be given as to just how innovative this application of the household concept is. If it is developed further in the $\mathrm{PE}$, it is nonetheless already present in Paul to some degree through the stewardship concept (oikovónos, oikovouía; 1 Cor. 4:1-2; 9:17; Col. 1:25) and through the concept of membership in the household of faith (oi oikeior

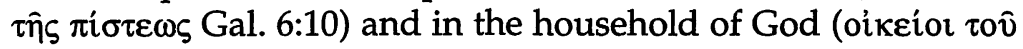

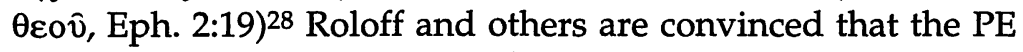
reflect the tendency of the third generation church to retreat to a conservative, patriarchal social church arrangement centred on the household in response to enthusiasm and particularly to the emancipation of women inspired by early Paul.29 But this is just one reading of the texts, which in fact is as rigid and predetermined as Baur's was. A case for development in the use of a concept can certainly be made, but it remains to be seen whether the household imagery of the Pastorals has completely broken loose from Pauline thought.

Moreover, Roloff's interpretation of the church in 1 Timothy 3:15 gives rise to a question concerning exegetical method. Who makes the rules for determining when an allusion is present in a text? Consider briefly his line of thought. (1) The occurrence of the phrase 'living God' leads to

28 See P.H. Towner, 'Household and Household Codes', in G.F. Hawthorne \& R.P. Martin (eds.) The Dictionary of Pauline Literature (Downers Grove/Leicester: IVP, 1993) 417-19.

${ }^{29}$ Roloff, Der erste Brief an Timotheus, 135-7; $c f$. E. Schüssler Fiorenza, In Memory of Her (New York: Crossroad, 1984) 261-6. 
the conclusion that 2 Corinthians 6:16 (which reads, 'we are the temple of the living God') is behind the passage; (2) the language 'pillar and foundation' confirms an allusion to temple imagery, though the word for temple (vaós) present in early Pauline texts and in Ephesians 2 is not present in 1 Timothy 3:15. If we assume that Roloff is right and that these allusions are present, why not go the next step and assume that the presence of the Holy Spirit must also be alluded to; after all in Old Testament and especially New Testament texts, temple and Holy Spirit go together automatically. Furthermore, in 1 Corinthians 3:16, which must bear some relationship to 2 Corinthians 6:16, the Holy Spirit is said to indwell the temple of the church. Apparently, Roloff understands the writer to envisage the church as the temple without the Spirit. Whether the break-up of the temple-Spirit association would even be possible in an early Christian church should perhaps be given further consideration. In view of the dominance of the association elsewhere in the biblical and extra-canonical tradition, the absence of a specific reference to the association here only proves that it did not suit the text. In fact, however, the absence of a reference to the temple in a context in which 'household' imagery (o'kos) dominates suggests another possibility. For a predominantly Gentile readership, is it not just as reasonable to think that temple imagery was simply passed over in this description in favour of Greco-Roman household imagery?

It also worries Roloff that the imagery of growth is absent from this picture of the church, and is replaced instead with images of solidity and permanence. Growth is indeed a dynamic image in the earlier Paul, and it occurs in connection with the body concept (Eph. 4:15-16; Col. 2:19) and in discussions about the missionary task (1 Cor. 3:6-7). Perhaps it should worry him more that the thought of growth is missing from 2 Cor. 6:16. But in any case, the thought of permanence, properly understood, is not missing from Paul (cf. Rom. 8:31-9). It is, however, not the thought of historical permanence of any particular church that marks the new people of God, but the assurance of unshakeableness that comes through promise. The uncertainty of the 'already-not yet' situation applies to the 
local expression of the church; but the fulfilment of God's plan for the church in history and eternity is certain because of his promises. Which side of the truth, permanence or impermanence, maturity or growth, is expressed may, however, depend upon the particular context. What imagery better suits the parenetic situation of 1 Corinthians? That church needed to refocus on the fact that God's church is in process. 30 But in the context of 1 Timothy, with heresy threatening the gospel, images of strength and certainty remind the readers of the presence and promises of God, and call believers back to a new effort in the church. ${ }^{31}$ The stance is different. The later description may show development in a theology of the church, but we need to ask if that development is due to a different mind (or rather to a different mindset) caused by new circumstances. But lack of growth imagery does not amount to the conclusion that the church here is the great historical institution in the world. That is read into the text primarily because of the metaphor of the household.

On the whole, as we re-examine Roloff's methodology and guiding principles, we find evidence at most of transition, but transition marked by continuity rather than discontinuity. In treating the text, Roloff has attempted a precision in his exegesis of the parts, and especially the architectural parts, of the church picture that exceeds the purpose of the text. In fact, 1 Timothy 3:15 combines images, the dominant one being the household, in order to bring together several key points which might not have been immediately evident to the readers, or which they might have been ignoring: (1) Just as membership in God's family implies tremendous privileges (cf. Eph. 2:1921), it also carries with it obligations and responsibilities; i.e. godly behaviour and order in the church are essential to membership in God's household. (2) Why is this? Because within the context of this literary section (2:1-3:13), the success of the church's gospel ministry is directly related to Christian

30See A.C. Thiselton, 'Realised Eschatology at Corinth', NTS 24 (1978) 51026.

31For a comparison of the outlooks at Corinth and Ephesus, see P.H. Towner, 'Gnosis and Realised Eschatology in Ephesus (of the Pastoral Epistles) and the Corinthian Enthusiasm', JSNT 31 (1987) 95-124. 
behaviour and church order, but the emphasis is on the former; the priority in the bishop and deacon codes is not on church organisation as such, but on proven character. To bring these ideas together the writer combines images of the church as a household with a strong picture of the church in its gospel carrying function. Below, in 3:16, the inter-relatedness of godliness and the gospel is emphasised. The people of God exist for God, for the gospel (the truth) and for the salvation of the world. Such a theme may lie beneath the surface in the earlier Paul, as a close look at Philippians 2:12-18 might suggest; there too it is possibly the absence of the apostle that forces a reconsideration of the church's role in God's plan.

\section{An Alternative Approach: Pauline Theology in Transition}

The process engaged in above has been one of separating exegetical results from the assumptions and methods by which they are interpreted. Some of the results produced by Roloff and the modern consensus stand. But we have seen that they do not validate the assumptions which lie behind the controlling question, Why would a third generation writer produce the Pastorals? The exegetical results reveal a theology of the church that is distinctive and marked by development, and suggest a transitional situation. But they do not substantiate Roloff's claim that the transition in view is from the second to the third generation of Christianity, nor that 'distinctiveness' and 'development' mean discontinuity in relation to Pauline theology. These conclusions rest wholly upon assumptions which the text itself does not require.

The transition which the text itself reflects suggests at least three other possible questions which might establish a viable research agenda. (1) What combination of circumstances would have caused a co-worker or student of Paul to write the PE shortly after Paul's death? (2) What combination of circumstances might have motivated Paul to write the PE? (3) Is it possible that Paul's thoughts on what would happen when he went could have been developed by a colleague? 
As we have seen, once the rigid framework is slipped out of the interpretation that it supports, the exegetical results are free to take a new shape. Either of the three vantage points just suggested allows an alternative interpretation which can affirm both the elements of theological development and historical transition, but which can also understand the theology of the Pastorals to be Pauline in a substantial sense.

From an evaluation of the theology of the church, I would suggest that it is possible to understand the theology of the PE as reflecting a transitional stage in Pauline theology. Roloff might seem to say the same thing, but he does not. None of the evidence proves that the transition reflected in the PE is from the second to the third generation of Christianity. The text suggests that the main aspect of transition involves the event of the absence or the departure or imminent departure of the apostle, which points to a transition from first to second generation Christianity. The influence of this transition on the theology of the church, as well as on other aspects of theology, would be felt through a series of questions about its potential practical implications. And it is the following sorts of questions that the theology of the church in the Pastorals seeks to answer.

First, what will happen to the Pauline mission? The answer is given by way of an increased interest in the church's role in relation to the gospel. What was formerly the apostle's role must be passed on to his co-workers and to the church. In the past decade studies have noticed that Paul tends to think of the task of proclamation as belonging mainly to him and his team, not to the church. ${ }^{32}$ That view may need to be adjusted somewhat; but the PE do reflect a new emphasis in the concern expressed for the transmission and succession of the gospel. A new or more thorough understanding of the church's responsibility in mission emerges. The historical event of the apostle's departure forces theology, which is probably already latent in the church's thinking (cf. Phil. 2:12-18), to develop.

Second, however, we must notice that the church that now carries on the Pauline mission is not a church at rest. Images of the church are combined in new ways in a discourse

${ }^{32} C f$. P. Bowers, 'Church and Mission in Paul', JSNT 44 (1991) 89-111. 
which addresses a new set of circumstances. But a great distance from Paul is not necessarily required for this to happen. The church may be thought of as complete in the sense that its existence is the fulfilment of the Old Testament promise to gather in the Gentiles, and in the sense that Paul has fulfilled his ministry. It may be conceived of as God's household. But the household concept serves a perfectly understandable parenetic function in its passage(s) and may also have to be understood as part of a broader response to a heretical disregard for social institutions (1 Tim. 4:3; 5:1-16; 6:1-2). But in any case, alongside thoughts of the church's permanence must be placed thoughts of its vulnerability. Immediately following the picture of the church in 3:15 comes the warning in 4:1 of the threat to it posed by heresy, given in a salvation-historical mode. The permanence of any given representation of God's church is constantly challenged by the threat of impermanence.

Third, the paradox of impermanence presented to the church in the emergence of a particularly virulent heretical movement in Ephesus at such a time underlines all the more the importance of preserving and transmitting the entire apostolic teaching intact. On the one hand, the challenge of false doctrine which is affecting an understanding of the message of salvation and the life it is meant to produce calls forth a new emphasis on teaching. On the other hand, faithful teachers must be found to whom the teaching can be entrusted for the next generation.

Fourth, the same turbulence caused by the heresy in the community inclines the theology of the church in the PE towards an interest in church leadership. But it is not organisation as such, much less a particular ecclesiastical arrangement, that is clearly an intrinsic part of this theology. Bishops and deacons already exist in some kind of official arrangement, just as they do in other Pauline churches. The accent in this dimension of ecclesiology falls on the quality of character exhibited by leaders and those who would be leaders. If some of the leadership had actually fallen to the heresy or had caved in under the pressures related to the disputes it caused, this concern is most understandable. But the 
continuation of the church after the apostle departs depends upon godly leaders, not a rigid official structure.

New accents and developments in the theology of the church are in evidence in the Pastorals. But it is not necessary for these developments to be either historically or theologically disconnected from Paul. Rather, Pauline theology takes the shape demanded by the transition from the first to the second generation. Reflection on the implications of Paul's departure, especially in the face of current heresy, is sufficient stimulus to produce letters which seek to re-evaluate and certify the content and role of the gospel and the nature and role of the church in God's salvation plan. There is no reason to think that such reflection must be placed at the turn of the century. 